An Integrated System for Production of Noutronics and Photonics Calculational Constonis Volume 19

\title{
NEUTRON-INDUCED ANGULAR AND ENERGY DISTRIBUTIONS: CRAPHICAL EXPERIMENTAL DATA
}

D. E. Gullen, R. J. Howerton, M. H. MacGregor, and S. T. Perkins

Apr11 1, 1977

Prepared for U.S. Energy Research \& Development Administration under contract No. W-7405-Eng-48

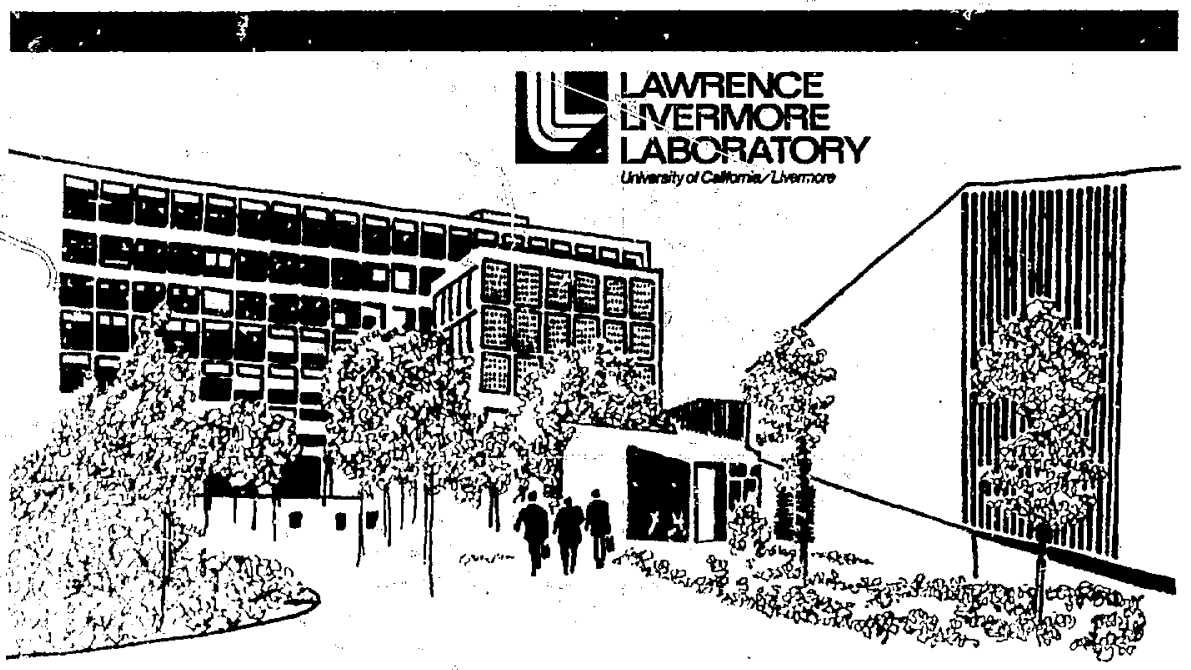


$\because$

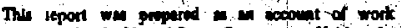

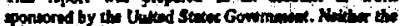

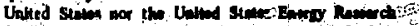

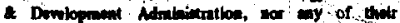

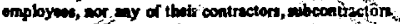

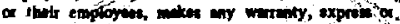

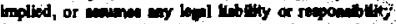

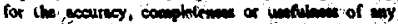

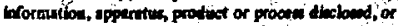
repreante the It an wort not infring petuately-owned state.

\section{NOTKE}

Rifertice to a conpugy of product nume does not inty epproxal or recominendition of the product by

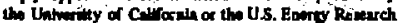
\& Developinat Admindititon to the exclution of ollor that mas be witchle.

Printed in the United States of America Avallable from

National Technical information Service

U.S. Depurtment of Cominerce

5285 Purt Royal Rond.

Springfield, VA 22161.

Price: Printed Copy 5 ; Micruficho $\$ 3.00$

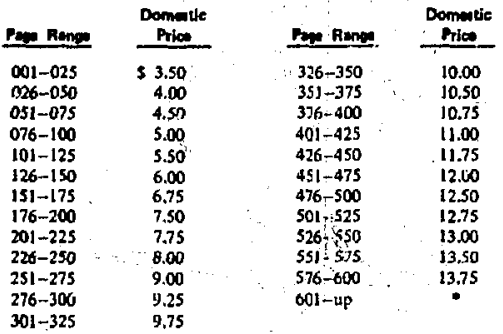

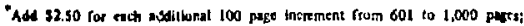
w1,30 for axh additiont 100 page increment oves 1,000 pase.. 


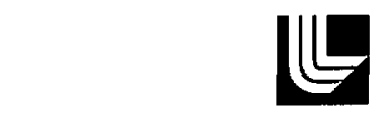

\section{LAWRENCE LIIVERMORE LABORATORY}

University of Cabtomia Livermore, California 94550

UCRL-50400 Volume 19

\section{NEUTRON-INDUCED ANGULAR AND ENERGY DISTRIBUTIONS: GRAPHICAL EXPERIMENTAL DATA}

D. E. Cullen, R. J. Howerton, M. H. MacGregor, and $S . T$. Perkins

MS date: April 1, 1977 


\section{Foreword}

The UCRL-50400 sertes describes an Integrated and computer-orlented system for the production and application of neutronics and photonics calculational constants.

The system must supply reliable up-to-aate data, select specific types of data on request, provide output in a varlety of forms - ultimately in the form of input to other computer codes - and function rapidly and efficiently. The system has now been developed to a point where these goals are belng realized.

The UCRI-50400 serles, An Integrated System for Production of Neutronics and Photonics Calculational Constants, comprises tine following volumes:

- Vol. 1 Rev. 3, ECSIL, A system for Storage, Retrieval and Dis.play of Experimental Neutron Data, to be published in September 1976.

- Vol. 2 Rev. 2, Neutron-Induced Interactions: Bibliography of Experimenta? Data, July 1976.

- Vol. 3 Rev. 2, Neutron-Induced Interactions: Index of Experimental Data, July 1976.

- Vo1. 4, Evaluated Nuclear CrossSection Library, Apr11 1971.

- Vol. 5, Rev. 1, CLYDE: A Code for the Produation of Calcula- tional Constants from Nuclear Data, September 1975.

- Vo1. 6, Rev. 1, Tables and Graphs of Photon Interaction Cross Sections from $1.0 \mathrm{keV}$ to $100 \mathrm{MeV}$ Derived from the $L L L$ Evaluated Nuclear Data Library, october 1975.

- Vo1. 7 Part A Rev. 1, Major Neutron-Induced Interactions $(Z \leq 55)$ : Graphical, Experimentai Data, July 1976.

- Vo1. 7 Part B Rev. 1, Major Neutron-Induced Interactions (Z > E5): Graphical, Experimental Data, July 1976.

- Vo1. 8 Rev. 1 Part A, Supplemental Neutron-Induced Interactions ( $Z \leq 35)$ : Graphical, Experimental Data, July 1976.

- Vol. 8 Rev. 1 Part B, Supplemental Neutron-Induced Interacitons $(Z>35)$ : Graphisal, Experimental Data, July 1976.

- Vol. 9, Thresholds of Nuclear Reactions Induced by Neutrons, Photons, Deuteruns, Tritons, and Alpha Particles, September 1970.

- Vo1. 10, Tabulated Experimental Data for Neutron-Induced Interactions, July 1976.

- Vol. 11, Experimental Data, indexes and Techniques of obtaining a selected set of 
Neutron Resonance Parometers, May 1972.

- Vo1. 12, An Atzas of Resolved Neution Resonance Parameters, July 1972.

- Vo1. 13, An Atlas of Unresolved lieutron Resonance Parameters, September 1972.

- Vol. 14, TARTNP: A Coupled Neutron-Photon Monte Carlo Transport Code, July 1976.

- Vol. 15, Part A, The LLL Evaluated Nuclear Data Library (ENDL): Evaluation Techniques, Reaction Index, and Descriptions of Individual Eiraluations, September 1975.

- Vol. 15, Part B, The LLL Evaluated Nuclear Data Libramy (ENDL): Graphs of Cross Sections from the Library, April 1976.
- Vol. 15, Part C, The LLL Evaluated Nuclear Data Library (ENDL): Transiation of ENDL Neutron-Induced Interavtion Data into the ENDF/B Format, April 1976.

- Vo1. 16, Tabuzar and Graphical Presentation of 175 Neutron Group Constants Derived from the LLE Evaluated Neutron Data Library (ENDL), April 1976.

- Vol. 17, Utility Codes for the Processing of Evaluated Data.

- Vo1. 18, ACTL-Evaluated Neutron Activation Crose Seation Library (1977).

- Vol. 19, Neutron Induced Angular and Energy Distributions: Graphical Experimental Data, Apr11 1977. 


\section{Contents}

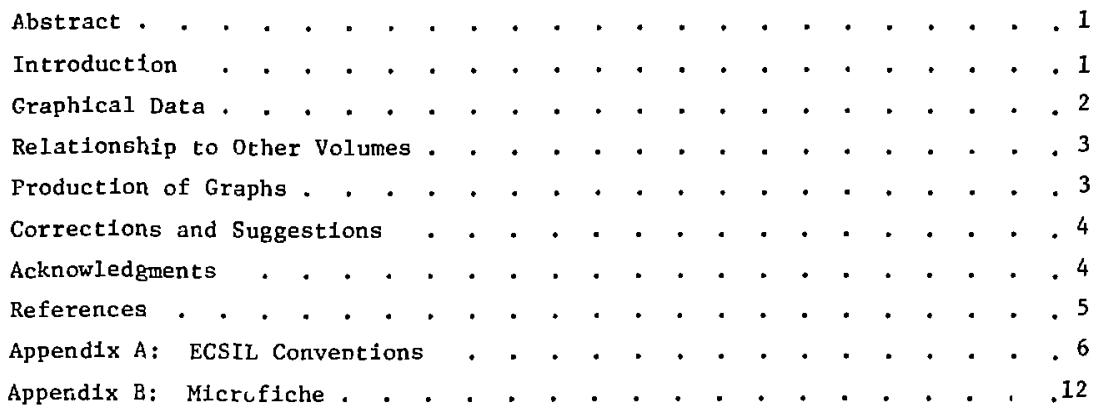




\section{NEUTRON-INDUCED ANGULAR \\ AND ENERGY DISTRIBU'TIONS: \\ GRAPHICAL AND EXPERIMENTAL DATA}

\section{Abstract}

We have generated graphs of neutron-induced distributions based on the data found in the Exrerimental Cross Section Information Lfbrary (ECSII) as of Apr11 1, 1977. Angular and energy distributions as well as
Legendre coefficients have been presented for all secondary particles emitted from the nucleus (e.g., neutrons, protons, deuterons, etc). We have plotted the data with error bars when they have been avaflable.

\section{Introduction}

In 1958, Lawrence LIvermore Laboratory (LLL) Installed a computer system to store and retrieve experimental neutron interaction data. This system, the Experimental Cross Section Information Library (ECSII), has developed gradually and is still being improved.

The present ECSIL syotem ${ }^{1}$ comprises :wo separate reference files: a numerical daca file and bibliographic information file. The two files are linked through the use of a four-digit number uniqueiy assigned to each reference.

In 1959 and 1960, LLL published tabulations of integrated and differ- ential neutxon cross sections below $15 \mathrm{MeV}$. Since that time, the number of entries in the system has tncreased by more than an order of magnttude. Consequently, the current library corttains too much data (over 1.t million data polnts) to publish tabulations; the rasulting volumes would be prohibitively expensive and rulk $\%$ However, by presenting the da:a in graphs $^{2,3}$ and on microfiche, ${ }^{4}$ we can significantly reduce expensc and bulk. Moreover, bulk reduation ae:ane that indexes ${ }^{5}$ and byblio: raphies $^{6}$ can be added to help in data manipulation. 


\section{Graphical Data}

The present ECSIL system contains 136048 angular distribution data points $(\mathrm{C}=101-149),{ }^{*} 12684$ Legendre coefficlents ( $C=451-499$ ), and 11678 energy distribution data points $(c=201-249)$. Since $1 t$ takes almost 10000 plots to graph these data, the." have been put on microfiche. Users at Livermore may obtain printed coples of all or any portion of these data by contacting $M$. MacGregor of the Theoretical Physics Dept.

In this volume each data set ${ }^{\dagger}$ is plotted separately. The plots are presented in three separate sections:

- Angular distributions

- Legendre coefficlents

- Energy distributions Within each section the plots are ordered by ascending atomic number and welght. (See "ECSIL Conventions" for compounds and spectail materta1.)

Within each material the reactions are ordered by ECSIL C number. Within a given reaction the plots are ordered by Incident neutron energy. Reference number and year of reference appear to the left of the plot (e.g., ECSIL-3327 (68) Indicates ECSIL reference number 3327 and referenre data from 1968).

\footnotetext{
${ }^{*} \mathrm{C}$ number refer to ECSIL $C$ numbers: see ECSIL Conventions.

$t_{t}$ data set in this context inciudes the data from a given reference for a single target and reaction.
}

An angular distribution, energy distribution, or set of Legendre coefficlents contalning four or more polnts is plotted. Data sets with fewer points are listed at the end of each material (ZA) In ECSIL $C$ order.

In general each plot represents a fixed incident noutron anergy, and the absitssa is elther the

- Casine of the scattering angle (see ECSIL conventions for the Laboratory or center-of-mass systems)

- Legendre order

- Secondary energy

However, when appropriate, the Incident neutron energy may be plotted along the abscissa fur either a fixed cosine, flxed Legendre order, or fixed secondary energy. This convention is more appropriate for the representation of certain experImental data; for example:

- Measurement at a fixed anble

- Derivation of an average scattering cosine $\vec{\mu}$

- Measurement of excitation functions

In most cases the distrihutions describe secondary neutrons. However, In the case whire there is no neutron In the exit channel the distribution will be for another particle [e.g. $(n, \alpha)-\alpha$ particle; $(n, x) \gamma-$ photon, etc. ]. 


\section{Relationship to Other Volumes}

This volume is closely related to other volumes in the UCRL-50400 serles and can be used to determine whether experimental data are available for a given target and reaction. The following volunes provide other paths t.o the Information:

- Volume 1 describes the format and conventions associated with the library as well as the supporting system of programs. It. also gives the forms (e.g., lits and listings) and the order in which data and bibliographic information may be obtained.

- Volume 2 contalns bjbllographic Indexes that can be used to determine whether a spectflc reference is inciuded in the ECSIL system and which experimental data are associated with the reference.

- Volume 3 lists data indexes that may be used to determine the data in the library for a glven Isotope or reaction.
- viume 7 presents glaphs of all tota1, elastic, capcure, and fission Integral cross sections. It also supplies data on $\bar{v}$ (neutrons/fission), $\alpha$ (capture/ fieston ratio), and $\eta$ (neutrons/ nonelastic event).

- Volume 8 presents graphs of all other integrated (as opposed to angular distribution) cross sectlons, including $\left(n, n^{\prime}\right),(n, \alpha)$, etc.

- Volume 10 contains the ECSIL library contents tabulated on microfiche.

- Volume 11 1ists the indexes and tabulated iesonance parameters In ECSIL.

- Vozume 12 lists selected tabulated resolved resonance parameters.

- Volume 13 11sts selected tabulated unresolved resonanr 2 parameters.

See this vo:.ume's foreword for a list of associated volumes on evaluated data.

\section{Production of Graphs}

The computer program ECSPLT ${ }^{1}$ produced 111 of the graphs in this volume. The program required three noninteractive passes through the
ECSIL data library to produce microfiche of all the plots correctly ordered. These passes used $16 \mathrm{~min}$ of CDC-7600 time. 


\section{Corrections and Suggestions}

Users of these volumes have been a majo: ald in detecting and reporting erroneous data that have crept into ECSIL. They have also suggested Improvements in the format and scope of these volumes. Please continue to communtiate all corrections and suggestions to:

M. H. MacGregor

Theoret1cal Physles Dept., L-71

Untversity of Callfoinia Lawrence Livermore Laboratory P.O. Box 808

Livermore, CA 94550

\section{Acknowledgments}

We gratefully zcknowledge the cooperation of the National Nuclear Data Center at Brookhaven National Laboratory, Long Island, New York; the European Nuclear Energy Agency's center for collection of neutron data at Saclay, France; the International Atomlc Energy Agency Nuclear Data Section dt Vienna, Austria; and the Nuclear Data Center at ObnInsk, USSR. The National Nuclear Data Center h.ds routinely supplied us with expecimental data collected at the four centers. Many experimenters have furnlshed us with their data before publication. To them, espectally, we offer our grat $₫$ ful thanks. Finally, we would like to express our sincere gratitude to Violet Gamble and Sally Mooney for their efforts in maintaining the blbllographic file and to Kenneth H111 for ensuring that the aumerous computer runs were satisfactorfly completed. 


\section{References}

1. D. E. Cullen, R. J. Howerton, M. H. MacGreg'sr, and S. T. Perkins ECSIL, A Syetem for Storage, Retrieval and Diaplay of Expemimentai Data, Lawrence LIvermore Laboratory, Rept. UCRL-50400, vol. 1 (1976).

2. D. E. Cullen, R. J. Howerton, M. H. MacGregor, and S. T. Perkins, Major Neutron-Induced Interactions: Graphical, Experimertal Data, Lawrence L1vermore Laboratory, Rept. UCRL-50400, vol. 7 (1976).

3. D. E, Cullen, R. J. Howertor, M. H. MacGregor, and S. T. PerkIns, Supplemental Neutron-Induced Interactions: Graphical, Experimental Data, Lawrence LIvermore Laboratory, Rept. UCRL-50400, vol. 8 (1976).

4. M. H. MacGregor, D. E. Cullen, R. J. Howerton, and S. T. Perkins, TabuLated Experimental Data for Neutron-Induced Interactions, Lawrence LIvermore Laboratory, Rept. UCRL-50400, vol. 10 (1976).

5. M. H. MacGregor, D. E. Cullen, R. J. Howerton, and S. T. Perkıns, NeutronInduced Interactions: Index of Experimental Data, Lawrence Livermore Laboratory, Rept. UCRL-50400, vol. 3 (1976).

6. M. H. MacGregor, D. E. Cullen, R. J. Howerton, and S. T. Perkins, NeutronInduced Interactions: Bibliography of Experimental Data, Lawrence L1vermore Laboratory, Rept. UCRL-50400, vol. 2 (1976).

MSG/af,ml, sv/ $f f$ 


\section{Appendix A}

\section{ECSIL Conventions}

The ECSIL data system describes experimental neutron-induced cross sections and related information by Indicating:

- Target. The ZA number describas the target. There are several spectal conventions. For example, A is set at zero for elemental mixtures. For compounds, the $z$ of the element that appears first in the molecilar formula is used, and $A$ is defined as 300 plus the molecular weight (e.g., $\mathrm{H}_{2} \mathrm{O}$ is assigned $Z=1$ and $A=318$ ). For unstable targets, the longest-lived 1somer is assigned the ZA number of the target. Short-lived Isomers are assigned the $Z$ of the target, and $A$ is defined as 600 plus the atonic weight of the target (e.g., $242 \mathrm{~g}_{\mathrm{Am}}$ is assigned $\mathrm{Z}=95$ and $A=842$ ). See Table Al for a complete list of compounds and special isotopes.

- Interuation. A numerical equivalent is used to designate the type of interaction: total, elastic, capture, etc. In ECSIL, thIs numerical equivalent becomes the bastc C number. Table A2 gives a com- plete list of all basic C numbers.

- Interaction Property. A numerical equivalent designates the interaction properties that are measured, such as cross section, angular distribution, or energy distribution. In ECSIL, this numertcal equivalent becomes the $\mathrm{C}$-increment number. Tt. $t$ total $C$ number used to describe the interaction and 1 ts property Is the sum of the C-number fucrement nd the basic $C$ number (e.g., 11 -ndicates the total ' $\left.n, n^{\prime}\right)$ cross section, while 311 Indicates the $\left(n, n^{\prime}\right)$ secondary neutron energy spectrum). Table A3 gives a complete list of all C-number incremerts. Table A4 Ifsts miscellaneous quantities not included in the basic $C$-number/C-numberincrement scheme.

- Interaction Modifier. A numerisal equivalent is used to further qualify or describe the interaction. This quantity Indicates conditions such as target temperature, the cross section for excltation of one or more levels of the residual nucleus, and the cross section 
for production of one or more photons. In ECSIL, this numerical equivalent becomes the $\mathrm{S}$ number. Table A5 gives a complete list of all $\mathrm{S}$ numbers.

Table Al. Compounds and speclal isotopes (asslgned ZA's).

\begin{tabular}{|c|c|c|c|}
\hline $\begin{array}{l}\text { Asslgned } \\
\text { ZA } \\
\text { number }\end{array}$ & Material & $\begin{array}{l}\text { Assigned } \\
\text { ZA } \\
\text { number }\end{array}$ & Material \\
\hline 1302 & $\mathrm{H}_{2}$ (gas) & 14360 & $\mathrm{SiO}_{2}$ \\
\hline$: 308$ & $\mathrm{H}_{2} \mathrm{O}$ & 16364 & $\mathrm{SO}_{2}$ \\
\hline 1320 & $\mathrm{D}_{2} \mathrm{O}$ & 22349 & $\mathrm{~T}^{ \pm} \mathrm{H}_{0.6}$ \\
\hline 5370 & $\mathrm{~B}_{2} \mathrm{O}_{3}$ & 22350 & $\mathrm{TiH}_{1.9}$ \\
\hline 6328 & $\mathrm{C}_{2} \mathrm{H}_{4}$ & 26460 & $\mathrm{Fe}_{2} \mathrm{O}_{3}$ \\
\hline 6331 & $\mathrm{CH}_{3} \mathrm{OH}$ & 27650 & ${ }^{60 \mathrm{~m}} \mathrm{Co}$ \\
\hline 6376 & $\mathrm{C}_{6} \mathrm{H}_{6}$ & 40391 & $\mathrm{ZrH}_{0.63}$ \\
\hline 6384 & $\mathrm{C}_{6} \mathrm{H}_{12}$ & 40392 & $\mathrm{ZrH}_{0.98}$ \\
\hline 6386 & $\mathrm{C}_{6} \mathrm{H}_{14}$ & 40393 & $\mathrm{ZrH}_{1.5}$ \\
\hline 6392 & $\mathrm{C}_{3} \mathrm{H}_{8} \mathrm{O}_{3}$ & 40394 & $\mathrm{ZrH}_{1.98}$ \\
\hline 6404 & $\mathrm{C}_{8} \mathrm{H}_{8}$ & 40395 & zircaloy -2 \\
\hline 6492 & $\mathrm{C}_{10} \mathrm{H}_{8} \mathrm{O}_{4}$ & 40423 & $\mathrm{ZrO}_{2}$ \\
\hline 6652 & $\mathrm{C}_{25} \mathrm{H}_{52}$ & 52723 & $123 \mathrm{~m}_{\mathrm{Te}}$ \\
\hline 7328 & $\mathrm{~N}_{2}$ (gas) & 60636 & $\mathrm{Hd}_{2} \mathrm{O}_{3}$ \\
\hline 7353 & $\mathrm{NH}_{4} \mathrm{Cl}$ & 61748 & $148 \mathrm{~g}_{\mathrm{Pm}}$ \\
\hline 7398 & $\mathrm{NH}_{4} \mathrm{Br}$ & 82999 & RADIO-Pb \\
\hline 7445 & $\mathrm{NH}_{4} \mathrm{I}$ & 92570 & $\mathrm{UO}_{2}$ \\
\hline 8332 & $0_{2}$ (gas) & 95842 & $242 \mathrm{~g}_{\mathrm{Am}}$ \\
\hline 12340 & $\mathrm{MgO}$ & 95844 & $244 \mathrm{~g}_{\mathrm{Am}}$ \\
\hline 13402 & $\mathrm{Al}_{2} \mathrm{O}_{3}$ & 99854 & ${ }^{n}$ Es \\
\hline
\end{tabular}


Table A2. Basic reaction designator (bastc C).

\begin{tabular}{|c|c|c|c|}
\hline $\begin{array}{c}\text { Baslc } \\
\text { C } \\
\text { number }\end{array}$ & Cross-section type & $\begin{array}{c}\text { Baslc } \\
\text { C } \\
\text { number }\end{array}$ & Cross-section type \\
\hline 1 & Total & 25 & $\begin{array}{l}(n, x) \text { charged-particl } \\
\text { emission }\end{array}$ \\
\hline 2 & Elastic & 26 & $(n, p)$ \\
\hline 3 & Nonelast1c & 27 & $(n, X p)$ \\
\hline 4 & $\begin{array}{l}\text { Neutron emission (elastic } \\
+ \text { nonelast1c) }\end{array}$ & 28 & $(n, d)$ \\
\hline 5 & $\begin{array}{l}\text { Total scattering (Inelastic } \\
+ \text { elastic) }\end{array}$ & $\begin{array}{l}29 \\
30\end{array}$ & $\begin{array}{l}(n, x d) \\
(n, t)\end{array}$ \\
\hline 6 & Neutron nonelastic emisston & 31 & $(n, x t)$ \\
\hline 7 & Removal & 32 & $\left(\mathrm{n},{ }^{3} \mathrm{He}\right)$ \\
\hline 8 & - & 33 & $\left(\mathrm{n}, \mathrm{x}^{3} \mathrm{He}\right)$ \\
\hline 9 & - & 34 & $(n, \alpha)$ \\
\hline 10 & - & 35 & $(n, X \alpha)$ \\
\hline 11 & $\left(n, n^{\prime}\right)$ & 36 & Actlvation \\
\hline 12 & $(n, 2 n)$ & 37 & $(n, 2 a)$ \\
\hline 13 & $(n, 3 n)$ & 38 & - \\
\hline 14 & $\left(n, n^{\prime} p\right)$ & 39 & - \\
\hline 15 & $\left(n, n^{\prime} d\right)$ & 40 & - \\
\hline 16 & $\left(n, n^{\prime} t\right)$ & 41 & Bound atout \\
\hline 17 & $\left(n, n^{\prime}, 3_{\mathrm{He}}\right)$ & 42 & Free atom \\
\hline 18 & $\left(n, n^{\prime}, \alpha\right)$ & 43 & Coherent scattering \\
\hline 19 & $(n, 4 n)$ & 44 & Incoherent scattering \\
\hline 20 & - & 45 & Potential scattering \\
\hline $\begin{array}{l}21 \\
22\end{array}$ & $\begin{array}{l}\text { Abrorption } \\
\text { (n,ffssion) }\end{array}$ & 46 & 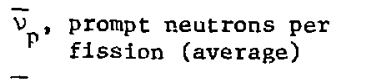 \\
\hline 23 & $(n, y)$ & 47 & 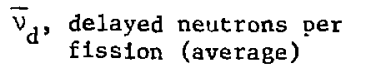 \\
\hline \multirow[t]{2}{*}{24} & $\begin{array}{c}(n, x y) \text { ganma-ray } \\
\text { production }\end{array}$ & 48 & $\begin{array}{l}n \text {, neutrons produced per } \\
\text { nonelastic }\end{array}$ \\
\hline & & 49 & $\alpha$, capture-to-flssion ratio \\
\hline
\end{tabular}


Table A3. Reaction designator Increments (C Increment).

\begin{tabular}{|c|c|c|}
\hline $\begin{array}{l}c \\
\text { Incre- } \\
\text { nent } \\
\text { number }\end{array}$ & $\begin{array}{l}\text { Reaction property } \\
\text { (units) }\end{array}$ & Definition \\
\hline 0 & $\begin{array}{l}\text { Integrated cross sections } \\
\text { (b) or related parameters }\end{array}$ & $\sigma$ \\
\hline 50 & $\begin{array}{l}\text { Spectrum-averaged cross } \\
\text { sections (b) }\end{array}$ & $\bar{c}$ \\
\hline $100^{\mathrm{a}}$ & $\begin{array}{l}\text { Angular distributions } \\
\text { (b/sr) }\end{array}$ & $\sigma(E, \theta)$ \\
\hline 200 & $\begin{array}{l}\text { Energy distributions } \\
(\mathrm{b} / \mathrm{MeV})\end{array}$ & $\sigma\left(E^{\prime}, E^{\prime}\right)$ \\
\hline $250^{2}$ & $\begin{array}{l}\text { Angular distributions } \\
\text { 1ntegrated between } \\
\text { fixed angular I1mits } \\
\text { (b) }\end{array}$ & $\sigma\left(E, \theta_{\min }, \theta_{\max }\right)_{1 a b}$ \\
\hline $300^{a}$ & $\begin{array}{c}\text { Differential energy dis- } \\
\text { tributions }(\mathrm{b} / \mathrm{sr} \mathrm{MeV})\end{array}$ & $\sigma\left(E, E^{\prime}, \theta\right)_{1 a b}$ \\
\hline $350^{a}$ & $\begin{array}{l}\text { Partial distributions } \\
\text { integrated between fixed } \\
\text { energy and angular limits } \\
\text { (b) }\end{array}$ & $\sigma\left(E, E_{\operatorname{m1n}}^{\prime}, E_{\max }^{\prime}, \Theta_{\min }, \theta_{\max }\right)_{1 a b}$ \\
\hline 400 & $\begin{array}{l}\text { Energy distributions } \\
\text { Integrated between fixed } \\
\text { energy limits (b) }\end{array}$ & $\sigma\left(E, E_{\min }^{\prime}, E_{\max }^{\prime}\right)$ \\
\hline $450^{\mathrm{a}}$ & $\begin{array}{l}\text { Legendre expansion of } \\
\text { angular distributions - } \\
g_{\ell}(E) \text { (dimensionless) }\end{array}$ & $\sigma(E, \Theta)=\sigma(E) \sum_{\ell=0}^{\infty} \frac{2+1}{4 \pi} g_{\ell}(E) P_{\ell}(\cos \Theta)$ \\
\hline 500 & Resonance Integrals (b) & R.I. $=\int_{E_{\min }}^{E_{\max }} \sigma(E) \frac{d E}{E}$ \\
\hline $550^{a}$ & $\begin{array}{l}\text { Polarizatio. (dimension- } \\
\text { less) }\end{array}$ & $P(E, \theta)$ \\
\hline $600^{a}$ & $\begin{array}{l}\text { Partial distributions } \\
\text { Integrated between } \\
\text { fixed-energy limits } \\
\text { (b/sr) }\end{array}$ & $\sigma\left(E, E_{\min }^{\prime}, E^{\prime \prime} \max ^{, \theta)} 1 \mathrm{ab}\right.$ \\
\hline $650^{a}$ & $\begin{array}{l}\text { Partial distributions } \\
\text { integrated between } \\
\text { fixed angular limits } \\
\text { (b/MeV) }\end{array}$ & $\sigma\left(E, E^{1}, \Theta_{\min }, O_{\max }\right) 1 a b$ \\
\hline 850 & $\begin{array}{l}\text { C/S ratios (dimension- } \\
\text { Iess) }\end{array}$ & \\
\hline 900 & Miscel laneous quantities & See Table 4 \\
\hline
\end{tabular}


Table A4. Reaction designator for miscellaneous quantities.

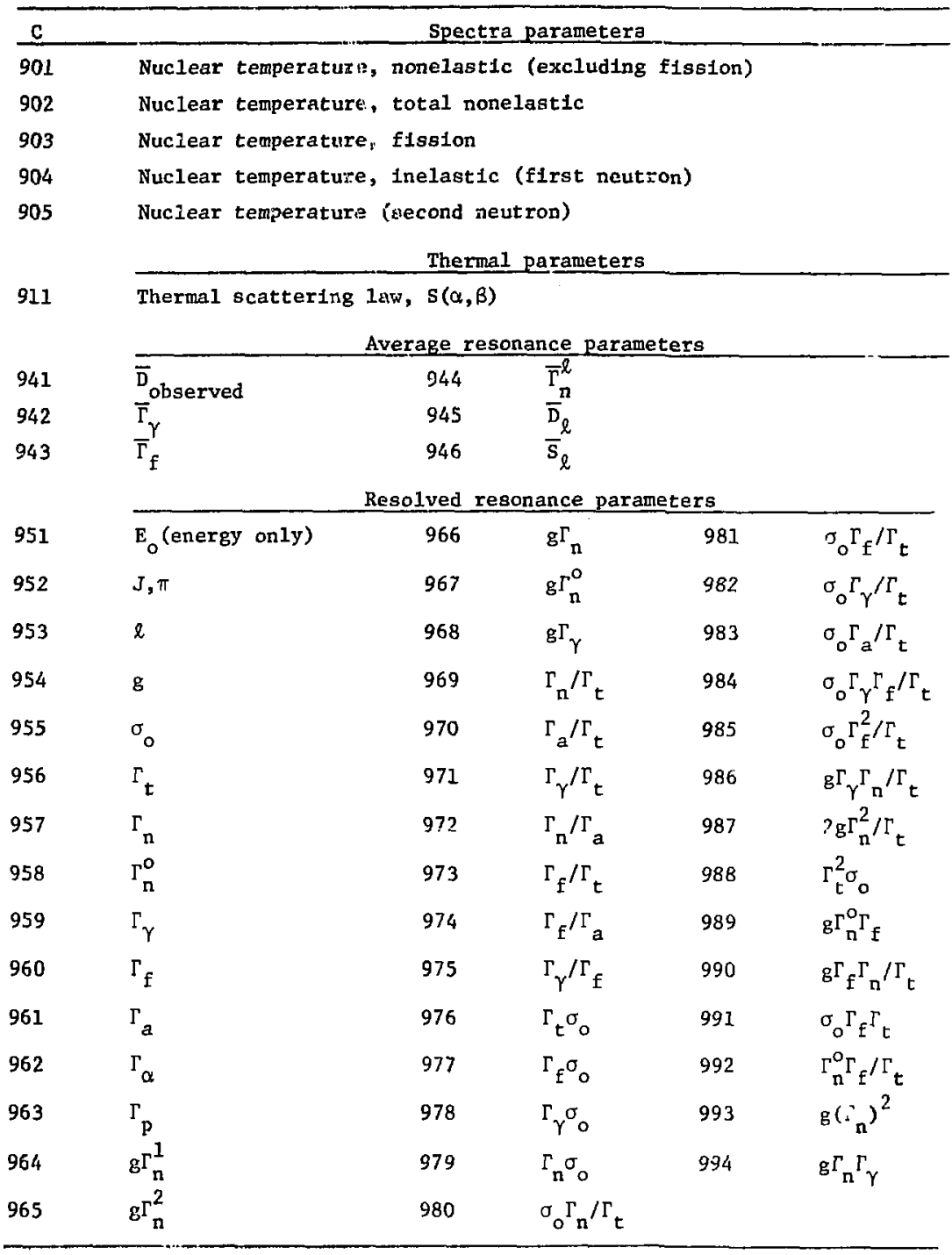


Table A5. Reaction designator modifier ${ }^{a}$ (S number).

\begin{tabular}{cl}
\hline S \\
number & \multicolumn{1}{c}{ Modification (units) } \\
\hline 1 & Level excitation (MeV) \\
2 & Isomer production (sec) \\
3 & Isomer production (min) \\
4 & Isomer production (hr) \\
5 & Isomer production (d) \\
6 & Isomer productior (yr) \\
7 & Photon production (Mev) \\
8 & Unresolved level excitation (MeV) \\
9 & Material temperature (K) \\
10 & Unresolved photon production (MeV) \\
11 & Spln state (dimensionless) \\
12 & Isotope bound in material (dimensionless) \\
13 & Orjented crystal (Miller number) \\
14 & Electron production (Mev) \\
20 & Trangmission measurement (b/atom) \\
\hline
\end{tabular}

${ }^{a_{S}}+80$ indicates relative distribution. 